BMJ Open

Diabetes

Research

$\&$ Care

\title{
High circulating plasma dipeptidyl peptidase- 4 levels in non-obese Asian Indians with type 2 diabetes correlate with fasting insulin and LDL-C levels, triceps skinfolds, total intra-abdominal adipose tissue volume and presence of diabetes: a case-control study
}

\author{
Shajith Anoop, ${ }^{1,2}$ Anoop Misra, ${ }^{1,2,3,4}$ Surya Prakash Bhatt, ${ }^{1,2}$ Seema Gulati, ${ }^{1,2}$ \\ Ravindra Mohan Pandey, ${ }^{5}$ Harsh Mahajan ${ }^{6}$
}

To cite: Anoop S, Misra A, Bhatt SP, et al. High circulating plasma dipeptidyl peptidase- 4 levels in non-obese Asian Indians with type 2 diabetes correlate with fasting insulin and LDL-C levels, triceps skinfolds, total intraabdominal adipose tissue volume and presence of diabetes: a case-control study. BMJ Open Diab Res Care 2017:5:e000393. doi:10.1136/ bmjdrc-2017-000393

\section{- Additional material is} published online only. To view please visit the journal online (http://dx.doi.org/10.1136/ bmjdrc-2017-000393).

Received 22 January 2017 Revised 19 July 2017 Accepted 16 August 2017

CrossMark

For numbered affiliations see end of article.

Correspondence to Dr Anoop Misra; anoopmisra@gmail.com

\section{ABSTRACT}

Aim To evaluate circulating plasma dipeptidyl peptidase-4 (DPP4) levels in non-obese Asian Indians with type 2 diabetes mellitus (T2DM), and to correlate these with metabolic profile and measures of anthropometry, skinfolds, abdominal adipose tissue depots, pancreatic volume, and liver span. Methodology Non-obese (body mass index (BMI) $<25 \mathrm{~kg} / \mathrm{m}^{2}$ ) patients with T2DM (cases, $n=93$ ), diagnosed within 1 year from recruitment, on metformin therapy and BMI-matched, and nondiabetic subjects (controls, $n=40$ ) were compared. Measurements of blood glucose, glycosylated hemoglobin, plasma insulin levels, lipid profile, hepatic transaminases and plasma DPP4 levels, and quantification of abdominal fat depots, pancreatic volume and liver span (MRI scan), were done. Results Significantly higher $(p<0.001)$ circulating plasma DPP4 levels were observed in cases as compared to controls. Specifically, in patients with T2DM with non-alcoholic fatty liver disease (NAFLD) $(n=48)$, the mean plasma DPP4 level $(52.6 \pm 27.8 \mathrm{ng} / \mathrm{mL})$ was significantly higher $(p<0.05)$ as compared with those without NAFLD $(n=43 ; 47 \pm 28.3 \mathrm{ng} / \mathrm{mL})$. Significant positive correlation was observed for circulating plasma DPP4 levels with waist-to-hip ratio, total intra-abdominal adipose volume, and liver span. Fasting serum insulin, low-density lipoprotein cholesterol (LDL-C), triceps skinfolds, total intra-abdominal adipose tissue volume and presence of T2DM were significant determinants of circulating plasma DPP4 levels.

Conclusion Non-obese Asian Indian patients with T2DM and on metformin therapy have significantly higher circulating plasma DPP4 levels as compared to nonobese non-diabetic controls, and these levels correlate with fasting insulin and LDL-C levels, upper limb subcutaneous adipose tissue, intra-abdominal adiposity and presence of diabetes.

\section{Significance of this study}

What is already known about this subject?

- The expression of dipeptidyl peptidase-4 (DPP4) has been shown to be dysregulated in obesity, type 2 diabetes mellitus (T2DM), non-alcoholic fatty liver disease and cardiovascular diseases. However, it is unclear if increased circulating plasma DPP4 levels are associated with the development of obesity and diabetes.

- Higher plasma DPP4 levels have been reported in obese as compared with non-obese individuals, but there are conflicting reports on circulating plasma DPP4 levels in subjects with T2DM of different ethnic groups.

What are the new findings?

- This is the first study reporting elevated levels of circulating plasma DPP4 in young, non-obese Asian Indian patients with T2DM, on metformin therapy and diagnosed within 1 year from onset. Further, elevated circulating plasma DPP4 levels in patients with T2DM correlate with measures of anthropometry, skinfolds, intra-abdominal adipose tissue and hepatic fat.

- We report fasting serum insulin, low-density lipoprotein cholesterol, triceps skinfolds, total intraabdominal adipose tissue volume and presence of diabetes as significant determinants of circulating plasma DPP4 levels in non-obese Asian Indians with T2DM residing in North India.

How might these results change the focus of research or clinical practice?

This study has significant implications for DPP4 inhibitors therapy in non-obese Asian Indians with T2DM. 


\section{INTRODUCTION}

Asian Indians have a body phenotype featured by excess body fat, higher truncal, subcutaneous and intra-abdominal adipose tissue, and lower muscle mass as compared with white Caucasians. ' 'Non-obese' Asian Indians (as defined by body mass index (BMI) $<25 \mathrm{~kg} / \mathrm{m}^{2}$ ) also exhibit similar body composition features with biochemical features of insulin resistance. Further, associated with type 2 diabetes mellitus (T2DM) in 'non-obese' Asian Indians are excess liver span and increased pancreatic volume (surrogate markers for ectopic fat deposition in liver and pancreas, respectively), as reported previously by our group. ${ }^{2}$ Despite these reports, the pathogenesis of T2DM in such 'non-obese' Asian Indians remains poorly understood.

Dipeptidyl peptidase- 4 (DPP4) is an exopeptidase glycoprotein of 110 kilodaltons released from differentiated adipocytes and ubiquitously expressed on the surface of a variety of cells and tissues such as pancreas, liver, spleen and adrenal glands. ${ }^{3}$ DPP4 exerts both paracrine and endocrine effects and is involved in cell signaling and insulin action. It selectively cleaves N-terminal dipeptides from cytokines, growth factors, neuropeptides and incretin hormones. ${ }^{4}$ The substrate for DPP4, namely glucagon-like peptide-1, is responsible for $60 \%$ of postprandial insulin secretion. It is inactivated by DPP4 within 20 minutes of release, ${ }^{5}$ leading to decreased plasma insulin levels resulting in elevation of blood glucose levels. ${ }^{6}$

The expression of DPP4 has been shown to be dysregulated in obesity, ${ }^{7}$ T2DM, non-alcoholic fatty liver disease $(\mathrm{NAFLD})^{8}$ and cardiovascular diseases. ${ }^{9}$ Higher plasma DPP4 levels have been reported in obese as compared with lean Chinese men. ${ }^{10}$ Further, circulating plasma DPP4 levels are increased in Danish patients with T2DM, ${ }^{11}$ while decreased plasma DPP4 levels were reported in Irish Caucasian patients with T2DM. ${ }^{12}$ In one of the few studies on correlations of DPP4 expression with abdominal adipose tissue compartments, circulating DPP4 levels was positively correlated with BMI, subcutaneous adipose tissue (SAT) and visceral adipose tissue (VAT) in German patients with wide ranges of BMI. Specifically, in lean subjects (mean BMI: $22 \pm 2 \mathrm{~kg} / \mathrm{m}^{2}$ ) with impaired glucose tolerance, DPP4 expression was higher in VAT than SAT, and correlated positively with the amount of VAT, adipocyte size and adipose tissue inflammation. It has been opined that DPP4 may be a marker for visceral obesity, insulin resistance and the metabolic syndrome. ${ }^{13}$ Preliminary data also show that circulating DPP4 levels correlated with advanced glycosylation end (AGE) products and that AGEs significantly increased plasma DPP4 release from tubular cells and increased DPP4 expression in Japanese patients, thus suggesting their potential importance in the development of complications of diabetes as well. ${ }^{14}$

DPP4 inhibitors have been used successfully in the treatment of T2DM globally. ${ }^{15}$ In this context, research on DPP4 is particularly relevant for Asian Indians who have increasing prevalence of diabetes, generalized obesity and excess abdominal adiposity. Importantly, adipose tissue compartments, posterior abdominal SAT ${ }^{16}$ and deep abdominal SAT have been strongly linked to insulin resistance, ${ }^{17}$ especially in Asian Indians. ${ }^{18}$

Previous investigators did not specifically study circulating plasma DPP4 levels in non-obese patients (defined by BMI) with T2DM. Importantly, the relationships of circulating plasma DPP4 with various adipose tissue subcompartments-abdominal SAT (anterior, posterior and deep subcutaneous abdominal adipose tissue) and total intra-abdominal adipose tissue, (intraperitoneal and retroperitoneal adipose tissue, pancreatic volume and liver fat, which may have relevance to insulin resistance, have not been previously defined.

In view of the above gaps in knowledge and pursuant to possible association of circulating plasma DPP4 to intra-abdominal obesity in non-obese Asian Indians with T2DM, we conducted the present research. We hypothesized that 'non-obese' Asian Indians with T2DM may have increased circulating plasma DPP4 levels as compared with non-obese, normoglycemic subjects and aimed to show that such increased levels would correlate with waist-to-hip ratio, skinfolds, abdominal SAT, intra-abdominal adipose tissue (IAAT) volume, liver span (as surrogate measure of NAFLD,) pancreatic volume (surrogate marker for pancreatic, lipids) and fasting serum insulin levels.

\section{METHODOLOGY}

Ethical approval was obtained from the institutional review board and the study was conducted according to the Declaration of Helsinki $2013 .{ }^{19}$ The details of subject recruitment, inclusion and exclusion criteria and so on are mentioned in our previous study. ${ }^{2}$

Briefly, non-obese (BMI $\left.\leq 25 \mathrm{~kg} / \mathrm{m}^{2}\right)$ patients with T2DM (cases: males $n=83$, females, $n=10$ ), diagnosed within one year from onset, and BMI-matched, normoglycaemic subjects (controls: males, $n=24$, females, $n=16$ ), aged between 18-40 years were recruited. In the first phase of the study, we recruited more of male T2DM subjects $(n=83)$ as compared with females $(n=10)$. This was because a higher number of male subjects fulfilled the recruitment criteria as compared to females.

None of the patients was on insulin therapy, sulfonylureas, DPP4 inhibitors, pioglitazone or any other antihyperglycemic treatment other than metformin. Those who were on metformin were continued on this drug and dose was modified as per clinical requirement. Peripheral skinfolds (biceps, triceps, thigh and calf skinfolds; sum of four skinfolds=total peripheral skinfolds) and truncal skinfolds (subscapular, suprailiac and abdominal skinfolds; sum of three skinfolds=total truncal skinfolds) were measured using a Lange skinfold calipers (Beta Technology, Santa Cruz, California, USA) as reported previously. ${ }^{20}$ Further, 1.5 Tesla MRI imaging was carried 
out using T1-weighted axial scans at lumbar vertebra 2 and 3 to estimate the volumes of total abdominal adipose tissue and abdominal adipose tissue compartments, viz SAT (anterior, posterior, superficial and deep subcutaneous) and total IAAT (intraperitoneal and retroperitoneal) with liver span (surrogate measure of NAFLD) and pancreatic volume, using previously published protocols. ${ }^{2}$ Pancreatic volume index was calculated as pancreatic volume $\left(\mathrm{cm}^{3}\right) /$ body surface area $\left(\mathrm{m}^{2}\right) .{ }^{21}$

\section{Biochemical analysis}

Fasting and postprandial blood samples were analyzed for plasma glucose levels. Serum lipid profile, hepatic transaminases and glycosylated hemoglobin were analyzed in fasting blood samples by methods described previously. ${ }^{2}$ Circulating plasma DPP4 and fasting serum insulin levels were measured by ELISA using commercial kits (USCN Life Science, Houston, Texas, USA). The intra-assay and inter-assay percentage coefficient variables for plasma DPP4 were 2.6 and 1.97, respectively. For serum insulin, the intra-assay and inter-assay percentage coefficient variables were 1.76 and 2.10 , respectively.

\section{Statistical analysis}

Data were analyzed using STATA 11.0 (College Station, TX, USA). Continuous variables were presented as Mean \pm SD using Student's t-test. As the data of cases and controls differed in age, the analysis of covariance (ANOCOVA) was used to adjust plasma DPP4 levels for age in cases and controls. The correlations of plasma DPP4 levels with measures of anthropometry, biochemical variables, and volumes of abdominal adipose tissue compartments, liver span and pancreatic volume were assessed using Pearson's correlation. Stepwise multiple regression analysis was performed to derive predictor variables for plasma DPP4 levels in both cases and controls. The $p$ value less than 0.05 was considered statistically significant.

\section{RESULTS}

In this study, significant differences were observed for biceps and triceps skinfolds in non-obese patients with T2DM (cases) as compared with controls after adjustment for age and gender (table 1). Importantly, significantly higher $(\mathrm{p}<0.001)$ circulating plasma DPP4 levels were observed in cases as compared with controls (table 2). Significantly higher volumes of abdominal adipose tissue depots were observed in cases as compared with controls, after adjustment for age and gender as follows: total IAAT $(49.7 \% ; \mathrm{p}=0.000)$, intraperitoneal adipose tissue $(47.7 \% ; \mathrm{p}=0.000)$, retroperitoneal adipose tissue $(70.7 \%$; $\mathrm{p}=0.000)$ and liver span $(10.8 \% ; \mathrm{p}=0.000)$. Specifically, no significant differences were observed between cases and controls for volumes of anterior subcutaneous, posterior subcutaneous, superficial and deep subcutaneous abdominal adipose tissue and total subcutaneous abdominal adipose tissue (figure 1A-F, table 3). Further, NAFLD was observed in 48 cases $(51.6 \%$; 36 cases had grade 1 and 12 cases had grade 2 NAFLD) and two controls (5\%; grade 1 NAFLD). Specifically, in patients with T2DM with NAFLD $(\mathrm{n}=48)$, the mean circulating plasma DPP4 level $(52.6 \pm 27.8 \mathrm{ng} / \mathrm{mL})$ was significantly higher $(\mathrm{p}<0.05)$ as compared with patients with T2DM without NAFLD $(\mathrm{n}=43$; mean circulating plasma DPP4 level; $47 \pm 28.3 \mathrm{ng} / \mathrm{mL}$ ).

Pearson's correlation analysis revealed significant positive correlation in cases for circulating plasma DPP4 with waist-to-hip ratio (online supplementary figure 1) and MRI quantified volumes of total IAAT $(\mathrm{p}<0.001)$ (figure 2$)$ and liver span $\mathrm{p}<0.05$ $(p<0.001) \quad$ (online supplementary figure 2$)$. No significant correlation was observed between plasma DPP4 levels in T2DM patients with NAFLD. Further, no significant correlation was observed for pancreatic volume and pancreatic volume index, anterior subcutaneous, posterior subcutaneous, superficial deep SAT compartments and total abdominal fat. For biochemical variables, significant positive correlation was observed for circulating plasma DPP4 levels with fasting insulin in cases but not in controls (online supplementary figure 3). Importantly, circulating plasma DPP4 levels correlated negatively and significantly $(\mathrm{p}<0.05)$ with high-density lipoprotein cholesterol (HDL-C) in cases but not in controls (table 4 and online supplementary figure 4).

On stepwise multiple linear regression analysis, variables such as fasting serum insulin, low-density lipoprotein cholesterol (LDL-C), triceps skinfolds, total IAAT volume and presence of T2DM were derived as significant determinants of circulating plasma DPP4 levels (table 5).

\section{DISCUSSION}

Although circulating plasma DPP4 levels in T2DM have been researched, data in non-obese patients with T2DM are few. This is the first study showing elevated levels of circulating plasma DPP4 levels in young, non-obese Asian Indian patients with T2DM. Further, for the first time, correlations of circulating plasma DPP4 with anthropometric measures (including detailed skinfold thickness measurements), volumes of abdominal adipose tissue compartments, pancreatic volume and liver span have been carried out.

Specifically, circulating plasma DPP4 levels correlated significantly and positively with waist-to-hip ratio and IAAT volume in T2DM cases as compared with controls, even after adjustment for age and gender. Further, on stepwise multiple linear regression analysis, total intra-abdominal fat volume appeared a significant predictor $(\beta$ coefficient: $0.40, \mathrm{p}<0.05)$ of circulating plasma DPP4 levels. Similarly, a recent CT-based study on elderly Japanese men with T2DM showed significant positive correlation between circulating DPP4 levels and intra-abdominal fat area, indicating that circulating DPP4 levels were 
Table 1 Anthropometric profile and skinfold measurements

\begin{tabular}{|c|c|c|c|c|c|c|}
\hline & \multicolumn{3}{|c|}{ Unadjusted for age } & \multicolumn{2}{|c|}{ Adjusted for age } & \multirow[b]{2}{*}{$p$ value } \\
\hline & Cases $(n=93)$ & Controls $(n=40)$ & $p$ value & Cases $(n=93)$ & Controls $(n=40)$ & \\
\hline Body mass index $\left(\mathrm{kg} / \mathrm{m}^{2}\right)$ & $22.8 \pm 2.0$ & $22.3 \pm 2.1$ & 0.21 & $22.8 \pm 1.9$ & $22.4 \pm 1.8$ & 0.33 \\
\hline Body surface area $\left(\mathrm{cm}^{3} / \mathrm{m}^{2}\right)$ & $1.72 \pm 0.1$ & $1.67 \pm 0.2$ & 0.09 & $1.7 \pm 0.09$ & $1.6 \pm 0.18$ & 0.97 \\
\hline Waist circumference (cms) & $85.7 \pm 6.8$ & $82.8 \pm 7.7$ & $<0.01$ & $85.8 \pm 4.8$ & $84.5 \pm 5.6$ & 0.02 \\
\hline Hip circumference (cms) & $89.5 \pm 4.6$ & $90.8 \pm 7.3$ & 0.23 & $89.3 \pm 4.8$ & $91.3 \pm 5.0$ & 0.06 \\
\hline Waist-to-hip ratio & $0.95 \pm 0.0$ & $0.90 \pm 0.0$ & $<0.001$ & $0.95 \pm 0.0$ & $0.90 \pm 0.0$ & $<0.001$ \\
\hline $\begin{array}{l}\text { Mid-arm circumference } \\
\text { (cms) }\end{array}$ & $27.2 \pm 2.4$ & $27.6 \pm 5.4$ & 0.6 & $27.2 \pm 2.8$ & $27.6 \pm 3.1$ & 0.53 \\
\hline $\begin{array}{l}\text { Mid-thigh circumference } \\
\text { (cms) }\end{array}$ & $49.7 \pm 4.2$ & $48.7 \pm 4.8$ & 0.24 & $49.7 \pm 3.8$ & $48.7 \pm 4.4$ & 0.26 \\
\hline Biceps skinfolds (mms) & $8.4 \pm 4.1$ & $13.6 \pm 9.8$ & $<0.01$ & $8.3 \pm 5.7$ & $13.8 \pm 6.3$ & $<0.01$ \\
\hline Triceps skinfolds (mms) & $15.6 \pm 5.3$ & $18.9 \pm 7.7$ & $<0.01$ & $15.5 \pm 0.3$ & $19.3 \pm 6.3$ & $<0.01$ \\
\hline Thigh skinfolds (mms) & $23.6 \pm 5.7$ & $28.7 \pm 10.1$ & $<0.01$ & $23.5 \pm 6.6$ & $28.9 \pm 7.5$ & $<0.01$ \\
\hline Calf skinfolds (mms) & $12.4 \pm 5.2$ & $21.8 \pm 8.4$ & $<0.01$ & $12.4 \pm 5.7$ & $21.9 \pm 6.3$ & $<0.01$ \\
\hline $\begin{array}{l}\text { Subscapular skinfolds } \\
\text { (mms) }\end{array}$ & $22.2 \pm 5.8$ & $21.8 \pm 8.5$ & 0.79 & $21.9 \pm 6.7$ & $22.3 \pm 6.9$ & 0.8 \\
\hline $\begin{array}{l}\text { Suprailiac skinfolds } \\
\text { (horizontal) (mms) }\end{array}$ & $17.8 \pm 4.9$ & $20.7 \pm 5.6$ & $<0.01$ & $17.7 \pm 4.8$ & $20.8 \pm 5.0$ & $<0.01$ \\
\hline $\begin{array}{l}\text { Suprailiac skinfolds (vertical) } \\
\text { (mms) }\end{array}$ & $18.1 \pm 5.2$ & $20.2 \pm 5.2$ & $<0.05$ & $18.0 \pm 9.6$ & $20.4 \pm 5.0$ & $<0.05$ \\
\hline $\begin{array}{l}\text { Suprailiac skinfolds } \\
\text { (average) (mms) }\end{array}$ & $17.9 \pm 4.8$ & $19.9 \pm 5.6$ & $<0.05$ & $17.8 \pm 9.6$ & $20.1 \pm 5.0$ & $<0.05$ \\
\hline $\begin{array}{l}\text { Abdominal skinfolds } \\
\text { (vertical) (mms) }\end{array}$ & $23.9 \pm 5.3$ & $24.1 \pm 7.8$ & 0.87 & $23.8 \pm 5.7$ & $24.6 \pm 8.1$ & 0.61 \\
\hline $\begin{array}{l}\text { Abdominal skinfolds } \\
\text { (horizontal) (mms) }\end{array}$ & $24.8 \pm 5.4$ & $24.1 \pm 7.6$ & 0.60 & $24.8 \pm 5.7$ & $24.6 \pm 8.1$ & 0.91 \\
\hline $\begin{array}{l}\text { Abdominal skinfolds } \\
\text { (average) (mms) }\end{array}$ & $24.2 \pm 5.3$ & $23.8 \pm 7.9$ & 0.71 & $24.0 \pm 5.7$ & $24.7 \pm 8.1$ & 0.66 \\
\hline $\begin{array}{l}\text { Total peripheral skinfolds } \\
(\mathrm{mms})\end{array}$ & $60.1 \pm 17.3$ & $78.0 \pm 35.2$ & $<0.01$ & $59.8 \pm 24$ & $78.7 \pm 23.9$ & $<0.001$ \\
\hline $\begin{array}{l}\text { Total truncal skinfolds } \\
\text { (mms) }\end{array}$ & $106 \pm 21.8$ & $102.0 \pm 29.6$ & 0.32 & $106.7 \pm 24$ & $101.9 \pm 25.2$ & 0.32 \\
\hline
\end{tabular}

Values are presented as Mean $\pm S D ; p<0.05$, statistically significant.

significantly associated with intra-abdominal visceral fat in Japanese patients with T2DM. ${ }^{22}$ Of note, as compared with white Caucasians, Asian Indians have higher magnitude of abdominal adiposity and larger adipocyte size ${ }^{23}$ correlating with increased release of non-esterified free fatty acids. ${ }^{24}$ It is reported that DPP4 levels correlate with adipocyte size and metabolic syndrome. ${ }^{10}$ Whether increased intra-abdominal obesity and larger adipocytes in non-obese Asian Indians lead to concomitant increase in DPP4 levels needs to be researched.

We used liver span quantified by MRI as a measure of hepatic fat, and also graded fatty liver. Importantly, nearly $52 \%$ of patients with T2DM in this study had NAFLD and elevated DPP4 levels. DPP4 is highly expressed in the liver tissues and its activity has been correlated with hepatic steatosis and grading of NAFLD in North Americans $^{25}$ and Japanese subjects. ${ }^{26}$ It is important to note that as compared with white Caucasians, hepatic triglyceride accumulation is significantly higher in Asian Indians and is associated with higher magnitude of insulin resistance. ${ }^{27}$ In this context, our observations being reported for the first time in Asian Indians achieve clinical importance. Further studies in the context of plasma DPP4 levels and liver steatosis in Asian Indians are needed, using more specific measures of quantification of liver fat (eg, proton magnetic resonance spectroscopy).

In our study, patients were non-obese by definition of BMI, hence circulating plasma DPP4 levels may not be similarly increased as seen in studies done on obese patients. Second, patients with T2DM in our study were diagnosed within oneyear prior to recruitment and were already on lifestyle management and metformin therapy. Whether such management could alter levels of circulating plasma DPP4 levels and its relationship with 


\begin{tabular}{|c|c|c|c|c|c|c|}
\hline \multirow[b]{2}{*}{ Biochemical variables } & \multicolumn{2}{|c|}{ Unadjusted for age } & \multirow[b]{2}{*}{ p value } & \multicolumn{2}{|c|}{ Adjusted for age } & \multirow[b]{2}{*}{$p$ value } \\
\hline & Cases $(n=93)$ & Controls $(n=40)$ & & Cases $(n=93)$ & Controls $(n=40)$ & \\
\hline $\begin{array}{l}\text { Fasting blood glucose } \\
(\mathrm{mg} / \mathrm{dL})\end{array}$ & $147.8 \pm 51.1$ & $89.4 \pm 2.6$ & $<0.000$ & $148.1 \pm 12.4$ & $88.8 \pm 32$ & 0.92 \\
\hline $\begin{array}{l}\text { Postprandial blood glucose } \\
\text { (mg/dL) }\end{array}$ & $222.6 \pm 82.9$ & $89.36 \pm 13.7$ & $<0.01$ & $222.9 \pm 70.5$ & $79.8 \pm 12.6$ & $<0.01$ \\
\hline $\begin{array}{l}\text { Fasting serum insulin } \\
\text { (mlU/dL) }\end{array}$ & $9.5 \pm 0.6$ & $5.5 \pm 0.4$ & $<0.001$ & $10.0 \pm 9.5$ & $6.8 \pm 8.1$ & $<0.05$ \\
\hline $\begin{array}{l}\text { Postprandial serum insulin } \\
(\mathrm{mlU} / \mathrm{mL})\end{array}$ & $22.3 \pm 3.0$ & $8.0 \pm 0.5$ & $<0.001$ & $21.5 \pm 44.6$ & $13.0 \pm 28.6$ & 0.07 (NS) \\
\hline Glycosylated hemoglobin (\%) & $9.00 \pm 2.5$ & $5.2 \pm 0.37$ & $<0.01$ & $9.0 \pm 2$ & $5.1 \pm 2$ & $<0.001$ \\
\hline Total cholesterol (mg/dL) & $175.4 \pm 41.5$ & $152.4 \pm 29.1$ & $<0.01$ & $175.4 \pm 38.4$ & $152.6 \pm 42.2$ & 0.34 \\
\hline Serum triglycerides (mg/dL) & $170.1 \pm 99.4$ & $97.15 \pm 45.8$ & $<0.01$ & $170.0 \pm 87.3$ & $97.4 \pm 88.2$ & $<0.001$ \\
\hline $\begin{array}{l}\text { High-density lipoprotein } \\
\text { cholesterol (mg/dL) }\end{array}$ & $40.7 \pm 8.9$ & $42.4 \pm 8.3$ & 0.31 & $40.8 \pm 8.6$ & $42.4 \pm 8.1$ & $<0.05$ \\
\hline $\begin{array}{l}\text { Low-density lipoprotein } \\
\text { cholesterol (mg/dL) }\end{array}$ & $110.3 \pm 31.2$ & $96.81 \pm 25.3$ & $<0.05$ & $110.2 \pm 29.7$ & $98.0 \pm 29.6$ & $<0.001$ \\
\hline $\begin{array}{l}\text { Very low-density lipoprotein } \\
\text { cholesterol (mg/dL) }\end{array}$ & $33.5 \pm 19.3$ & $19.47 \pm 9.1$ & $<0.01$ & $19.5 \pm 16.3$ & $33.5 \pm 17.0$ & $<0.001$ \\
\hline $\begin{array}{l}\text { Aspartate aminotransferase } \\
(\mathrm{U} / \mathrm{L})\end{array}$ & $57.81 \pm 21.7$ & $45.60 \pm 18.1$ & $<0.01$ & $57.9 \pm 20.1$ & $47.1 \pm 21.4$ & 0.17 \\
\hline $\begin{array}{l}\text { Alanine aminotransferase } \\
(\mathrm{U} / \mathrm{L})\end{array}$ & $27.89 \pm 12.8$ & $23.68 \pm 9.1$ & $<0.05$ & $27.8 \pm 11.5$ & $24.6 \pm 11.9$ & $<0.001$ \\
\hline $\begin{array}{l}\text { Serum } \\
\text { dipeptidyl peptidase- } 4 \\
(\mathrm{ng} / \mathrm{mL})\end{array}$ & $52.0 \pm 3.0$ & $20.1 \pm 2.3$ & $<0.001$ & $50.2 \pm 9.6$ & $23.5 \pm 6.3$ & $<0.001$ \\
\hline
\end{tabular}

Values are presented as Mean $\pm S D ; p<0.05$, statistically significant.

NS, not significant.

abdominal adipose tissue compartments is not known. In this context, it is important to note that in Korean patients with T2DM on metformin therapy or dual combination therapy (metformin with thiazolidinedione),
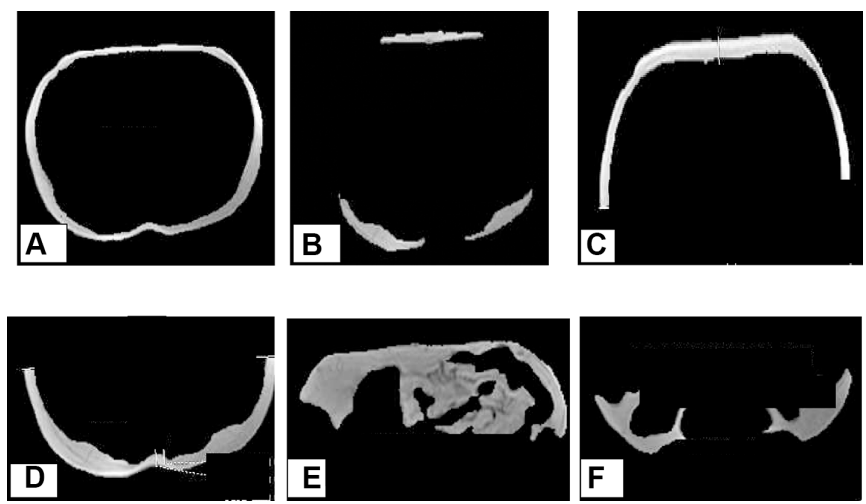

Figure 1 Abdominal adipose tissue depots and pancreatic volume in a 29 -year-old non-obese (BMI: $21.9 \mathrm{~kg} / \mathrm{m}^{2}$ ) patient with type 2 diabetes, images obtained using MRI (1.5 Tesla) and quantified by ROI analysis using GE Advantage Workstation Volume Viewer softwares. (A) Superficial subcutaneous abdominal adipose tissue, (B) Deep subcutaneous abdominal adipose tissue, (C) Anterior subcutaneous abdominal adipose tissue, (D) Posterior subcutaneous abdominal adipose tissue, (E) Intraperitoneal adipose tissue and (F) Retroperitoneal adipose tissue. plasma DPP4 levels were lower as compared to patients with T2DM on other antihyperglycemic drugs. These observations were attributed to the suppressive effects of metformin and thiazolidinedione drugs on the in vivo release of the plasma isoforms of DPP $4 .{ }^{28} 29$

Importantly, circulating plasma DPP4 levels have been reported to increase when $\mathrm{HbAlc}$ increases above $9.0 \%,{ }^{30}$ similar to patients in our study (HbAlc levels ranged between $9.0 \%$ and $11 \%(75-97 \mathrm{mmol} / \mathrm{mol}))$. We also show significant positive correlations of fasting insulin with high circulating plasma DPP4 levels. It is unclear if high levels of circulating plasma DPP4 as seen in patients with marked hyperglycemia is a primary or secondary effect. It is possible that gene expression for plasma DPP4 is upregulated on exposure to elevated blood glucose levels. ${ }^{31}$ In this context it is important to note that circulating plasma DPP4 levels are significantly upregulated by serum insulin levels ${ }^{32}$ and tumor necrosis factor alpha ${ }^{33}$, especially in patients with T2DM with non-alcoholic steatohepatitis. ${ }^{34}$ Importantly, circulating plasma DPP4 levels in peripheral blood cells improved after better glucose control in drug-naive T2DM patients with T2DM, indicating the possible role of DPP4 in insulin signaling pathway. ${ }^{33}$

Of further importance, we observed significant negative correlation of circulating plasma DPP4 levels with 
Table 3 Abdominal fat depots, pancreatic volume and liver span measured by MRI (1.5 Tesla)

\begin{tabular}{|c|c|c|c|c|c|c|}
\hline \multirow{2}{*}{$\begin{array}{l}\text { Variables measured by MRI } \\
\text { (1.5 Tesla) }\end{array}$} & \multicolumn{3}{|c|}{ Unadjusted for age } & \multicolumn{3}{|c|}{ Adjusted for age } \\
\hline & Cases $(n=93)$ & Controls $(n=40)$ & $p$ value & Cases $(n=93)$ & Controls $(n=40)$ & $p$ value \\
\hline $\begin{array}{l}\text { Anterior subcutaneous } \\
\text { adipose tissue volume }\left(\mathrm{cm}^{3}\right)\end{array}$ & $49.0 \pm 21.7$ & $46.7 \pm 20.1$ & 0.56 & $48.3 \pm 19.9$ & $48.4 \pm 20.7$ & 0.98 \\
\hline $\begin{array}{l}\text { Posterior subcutaneous } \\
\text { adipose tissue volume }\left(\mathrm{cm}^{3}\right)\end{array}$ & $55.8 \pm 20.6$ & $57.0 \pm 19.4$ & 0.75 & $55.2 \pm 19.9$ & $58.0 \pm 20.1$ & 0.41 \\
\hline $\begin{array}{l}\text { Superficial subcutaneous } \\
\text { adipose tissue volume }\left(\mathrm{cm}^{3}\right)\end{array}$ & $80.9 \pm 28.7$ & $82.4 \pm 30.8$ & 0.77 & $79.8 \pm 28.5$ & $84.8 \pm 28.9$ & 0.35 \\
\hline $\begin{array}{l}\text { Deep subcutaneous adipose } \\
\text { tissue volume }\left(\mathrm{cm}^{3}\right)\end{array}$ & $22.3 \pm 10.5$ & $19.6 \pm 8.3$ & 0.15 & $22.1 \pm 9.5$ & $20.3 \pm 9.4$ & 0.35 \\
\hline $\begin{array}{l}\text { Total subcutaneous adipose } \\
\text { tissue volume }\left(\mathrm{cm}^{3}\right)\end{array}$ & $103.3 \pm 35.3$ & $102.1 \pm 38.0$ & 0.86 & $101.9 \pm 35.1$ & $105.1 \pm 35.2$ & 0.64 \\
\hline $\begin{array}{l}\text { Retroperitoneal adipose } \\
\text { tissue volume }\left(\mathrm{cm}^{3}\right)\end{array}$ & $33.5 \pm 14.5$ & $19.6 \pm 9.0$ & $<0.001$ & $33.4 \pm 12.3$ & $19.9 \pm 13.2$ & $<0.001$ \\
\hline $\begin{array}{l}\text { Intraperitoneal adipose } \\
\text { tissue volume }\left(\mathrm{cm}^{3}\right)\end{array}$ & $69.3 \pm 29.5$ & $48.0 \pm 22.0$ & $<0.001$ & $62.2 \pm 27.5$ & $44.4 \pm 27.7$ & $<0.001$ \\
\hline $\begin{array}{l}\text { Total intra-abdominal } \\
\text { adipose tissue volume }\left(\mathrm{cm}^{3}\right)\end{array}$ & $102.8 \pm 39.8$ & $68.5 \pm 30.5$ & $<0.001$ & $69.1 \pm 37.0$ & $49.3 \pm 37.8$ & $<0.001$ \\
\hline Liver span (mm) & $165 \pm 16.5$ & $149.0 \pm 19.1$ & $<0.001$ & $165.1 \pm 17.1$ & $149.0 \pm 17.6$ & $<0.001$ \\
\hline Pancreatic volume $\left(\mathrm{cm}^{3}\right)$ & $67.4 \pm 24.9$ & $53.2 \pm 20.8$ & $<0.01$ & $67.1 \pm 23.7$ & $53.9 \pm 23.9$ & $<0.01$ \\
\hline $\begin{array}{l}\text { Pancreatic volume index } \\
\left(\mathrm{cm}^{3}\right)\end{array}$ & $38.7 \pm 13.8$ & $31.9 \pm 11.1$ & $<0.01$ & $38.6 \pm 12.3$ & $32.2 \pm 13.2$ & $<0.05$ \\
\hline
\end{tabular}

Values are presented as Mean $\pm S D ; p<0.05$, statistically significant.

HDL-C, despite lack of significant differences in mean values of HDL-C between the two groups. In a study on middle-aged Chinese individuals, HDL-C levels have been reported to correlate with plasma DPP4 levels only in subjects with diabetes and not in normoglycemic subjects. ${ }^{26}$ Similar observations have been reported in another study on Chinese individuals. ${ }^{10}$ Further in a study on non-obese, elderly Japanese subjects, HDL-C was shown to correlate independently with plasma DPP4 levels and showed significant dose-response relationship. ${ }^{14}$ This interesting relationship should be investigated. Finally, independent correlations of LDL-C and circulating DPP4 levels need to be researched in view of high predisposition of Asian Indians for development of coronary heart disease.

The clinical significance of high circulating plasma DPP4 levels in 'non-obese' Asian Indians with diabetes is not clear, but some reported effects could be relevant. Specifically, subclinical inflammation may be increased by plasma DPP4 due to induction of obesity-induced

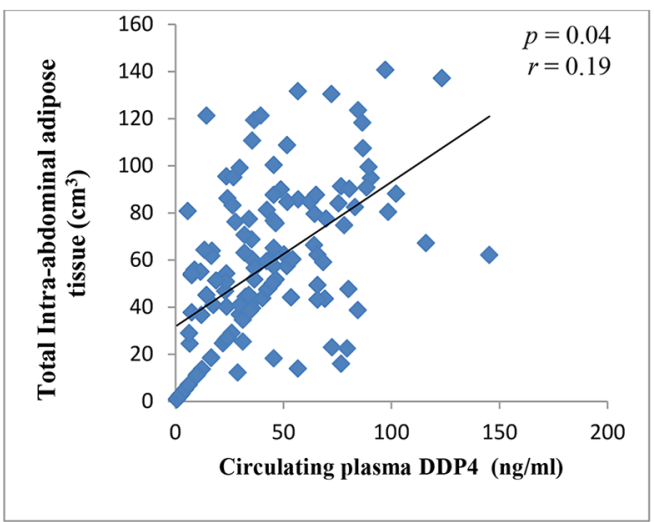

A

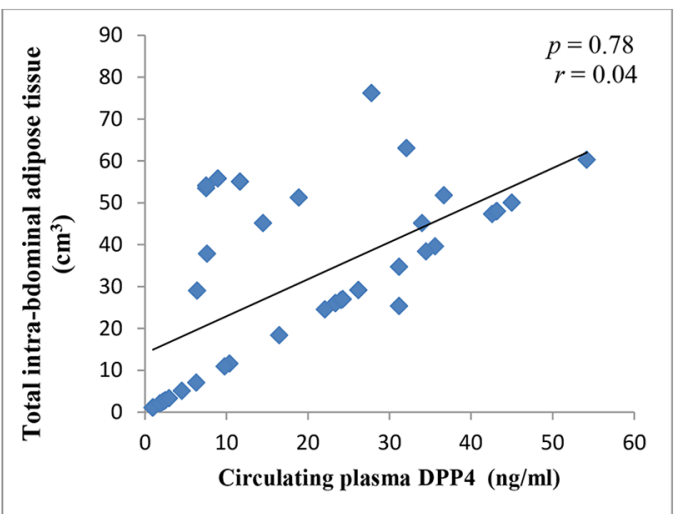

B

Figure 2 Showing significant positive correlation of circulating plasma DPP4 levels with total intra-abdominal adipose tissue volume in patients with T2DM (A) and lack of significant positive correlation of circulating plasma DPP4 with total intraabdominal adipose tissue volume in non-obese, non-diabetic subjects (B). DDP4, plasma dipeptidyl peptidase-4; T2DM, type 2 diabetes mellitus. 
Table 4 Correlation of plasma DPP4 levels with waist-to-hip ratio, biochemical variables, total abdominal fat volume and Liver span in non-obese patients with T2DM (Cases: $n=93$ ) and non obese, non diabetic subjects (Controls: $n=40$ )

\begin{tabular}{|c|c|c|c|c|}
\hline & \multicolumn{2}{|c|}{$\begin{array}{l}\text { Cases }(n=93) \\
\text { Pearson's correlation coefficient }\end{array}$} & \multicolumn{2}{|c|}{$\begin{array}{c}\text { Controls }(n=40) \\
\text { Pearson's correlation coefficien }\end{array}$} \\
\hline & $r$ & p value & $r$ & $p$ value \\
\hline Waist-to-hip ratio & 0.32 & 0.04 & 0.21 & 0.2 \\
\hline Fasting serum insulin (ng/dL) & 0.31 & 0.04 & 0.09 & 0.39 \\
\hline High density lipoprotein cholesterol (mmol/L) & -0.48 & 0.02 & 0.10 & 0.53 \\
\hline Total abdominal fat volume $\left(\mathrm{cm}^{3}\right)$ & 0.24 & 0.04 & 0.10 & 0.75 \\
\hline Total intra-abdominal fat volume $\left(\mathrm{cm}^{3}\right)$ & 0.19 & 0.04 & 0.04 & 0.78 \\
\hline Liver span (mm) & 0.24 & 0.02 & 0.10 & 0.98 \\
\hline
\end{tabular}

$\mathrm{p}<0.05$ : statistically significant.

DDP4, plasma dipeptidyl peptidase-4; T2DM, type 2 diabetes mellitus.

Table 5 Stepwise multiple linear regression analysis for determinants of circulating plasma DPP4 levels

\begin{tabular}{lcl}
\hline Predictor variables & $\begin{array}{l}\text { Beta coefficient } \\
\text { (95\% Cl) }\end{array}$ & p value \\
\hline Presence of diabetes & $7.1(5.0$ to 9.2$)$ & 0.001 \\
Fasting serum insulin & $0.23(0.09$ to 0.37$)$ & 0.04 \\
\hline $\begin{array}{l}\text { Triceps skinfold thickness } \\
\text { Total intra-abdominal fat }\end{array}$ & $0.25(0.11$ to 0.42$)$ & 0.02 \\
$\begin{array}{l}\text { volume }\left(\mathrm{cm}^{3}\right) \\
\text { Low-density lipoprotein } \\
\text { cholesterol }\end{array}$ & 0.80 (0.20 to 0.63$)$ & 0.001 \\
\hline
\end{tabular}

Adjusted $r^{2}$ value: $0.57, p<0.05$ : statistically significant.

DDP4, plasma dipeptidyl peptidase-4.

inflammation in IAAT ${ }^{35}$ Further, deterioration of insulin resistance and adiposity may be induced by high DPP4 levels. ${ }^{36}$ These effects of high DPP4 levels could be particularly detrimental to Asian Indians who already have higher magnitude of subclinical inflammation and abdominal adiposity as compared with other races, ${ }^{37}$ thus escalating cardiovascular risk. ${ }^{38}$ Whether high levels of circulating plasma DPP4 levels have any influence on therapy with DPP4 inhibitors remains to be researched. Finally, in view of high load of diabetes-related complications, the relationship of AGE products and circulating DPP4 levels in Asian Indians needs further research. ${ }^{39}$

In summary, non-obese Asian Indian patients with T2DM on metformin have significantly higher circulating plasma DPP4 level as compared with non-obese, non-diabetic controls, which correlate with fasting insulin and LDL-C levels, triceps skinfolds, and intra-abdominal adiposity, and presence of diabetes. However, this is a cross-sectional study and detailed studies on DPP4 expression in intra-abdominal adipocytes need to be conducted to validate our observations.

\section{Author affiliations}

${ }^{1}$ Centre of Nutrition \& Metabolic Research (C-NET), National Diabetes, Obesity and Cholesterol Foundation (N-DOC), New Delhi, India

${ }^{2}$ Diabetes Foundation (India), Safdarjung Development Area, New Delhi, India
${ }^{3}$ Fortis C-DOC Centre of Excellence for Diabetes, Metabolic Diseases and Endocrinology, Chirag Enclave, New Delhi, Delhi, India

${ }^{4}$ Department of Diabetes and Metabolic disorders, Fortis Flt Lt Rajan Dhall Hospital, New Delhi, India

${ }^{5}$ Department of Biostatistics, All India Institute of Medical Sciences, New Delhi, India

${ }^{6}$ Division of Metabolic Imaging, Mahajan Imaging Centre, New Delhi, India

Acknowledgements The authors thank the participants of this study. Mr Gokulraj Prabhakaran, Mahajan Imaging Centre, New Delhi, India, is acknowledged for technical support in MRI imaging.

Contributors AM conceived the study, reviewed and edited the manuscript. SA conducted the study and wrote the manuscript. SPB performed laboratory analysis of samples. SG contributed to the discussion and reviewed the manuscript. RMP analysed, interpreted the data and contributed to discussion. HM offered MRI services for the study. AM is the guarantor for this manuscript.

Funding A partial financial support towards imaging and laboratory investigation charges was received from Merck Limited, Mumbai, India (formerly E Merck). The Centre of Nutrition \& Metabolic Research (C-NET), New Delhi, India, supported staff salaries, costs for MRI imaging and DPP4 analysis in this study.

Competing interests None declared.

Patient consent Obtained.

Ethics approval Institutional ethics committee of Fortis C-DOC Centre of Excellence for Diabetes, Metabolic Diseases and Endocrinology, Chirag Enclave, Nehru Place, New Delhi.

Provenance and peer review Not commissioned; externally peer reviewed.

Open Access This is an Open Access article distributed in accordance with the Creative Commons Attribution Non Commercial (CC BY-NC 4.0) license, which permits others to distribute, remix, adapt, build upon this work non-commercially, and license their derivative works on different terms, provided the original work is properly cited and the use is non-commercial. See: http://creativecommons.org/ licenses/by-nc/4.0/

(C) Article author(s) (or their employer(s) unless otherwise stated in the text of the article) 2017. All rights reserved. No commercial use is permitted unless otherwise expressly granted.

\section{REFERENCES}

1. Misra A, Khurana L. Obesity-related non-communicable diseases: South Asians vs White Caucasians. Int J Obes 2011;35:167-87.

2. Misra A, Anoop S, Gulati S, et al. Body fat patterning, hepatic fat and pancreatic volume of non-obese Asian Indians with type 2 diabetes in North India: a case-control study. PLoS One 2015;10:e0140447.

3. Mentzel S, Dijkman HB, Van Son JP, et al. Organ distribution of aminopeptidase $A$ and dipeptidyl peptidase IV in normal mice. $J$ Histochem Cytochem 1996;44:445-61. 
4. Rohrborn D, Wronkowitz N, Eckel J. DPP4 in diabetes. Front Immunol 2015;27:6-386.

5. Deacon CF, Knudsen LB, Madsen K, et al. Dipeptidyl peptidase IV resistant analogues of glucagon-like peptide-1 which have extended metabolic stability and improved biological activity. Diabetologia 1998;41:271-8.

6. Drucker DJ, Nauck MA. The incretin system: glucagon-like peptide-1 receptor agonists and dipeptidyl peptidase- 4 inhibitors in type 2 diabetes. Lancet 2006;368:1696-705.

7. Stengel A, Goebel-Stengel M, Teuffel P, et al. Obese patients have higher circulating protein levels of dipeptidyl peptidase IV. Peptides 2014;61:75-82.

8. Williams KH, Vieira De Ribeiro AJ, Prakoso E, et al. Circulating dipeptidyl peptidase-4 activity correlates with measures of hepatocyte apoptosis and fibrosis in non-alcoholic fatty liver disease in type 2 diabetes mellitus and obesity: a dual cohort cross-sectional study. J Diabetes 2015;7:809-19.

9. Zhong J, Rao X, Rajagopalan S. An emerging role of dipeptidy peptidase 4 (DPP4) beyond glucose control: potential implications in cardiovascular disease. Atherosclerosis 2013;226:305-14.

10. Lamers D, Famulla S, Wronkowitz N, et al. Dipeptidyl peptidase 4 is a novel adipokine potentially linking obesity to the metabolic syndrome. Diabetes 2011;60:1917-25.

11. Ryskjaer J, Deacon CF, Carr RD, et al. Plasma dipeptidyl peptidaseIV activity in patients with type-2 diabetes mellitus correlates positively with $\mathrm{HbAlc}$ levels, but is not acutely affected by food intake. Eur J Endocrinol 2006;155:485-93.

12. McKillop AM, Duffy NA, Lindsay JR, et al. Decreased dipeptidyl peptidase-IV activity and glucagon-like peptide-1(7-36)amide degradation in type 2 diabetic subjects. Diabetes Res Clin Pract 2008;79:79-85.

13. Sell $\mathrm{H}$, Bluher $\mathrm{M}$, Kloting $\mathrm{N}$, et al. Adipose dipeptidyl peptidase-4 and obesity: correlation with insulin resistance and depot-specific release from adipose tissue in vivo and in vitro. Diabetes Care 2013;36:4083-90.

14. Tahara N, Yamagishi S, Takeuchi M, et al. Serum levels of advanced glycation end products (AGEs) are independently correlated with circulating levels of dipeptidyl peptidase-4 (DPP-4) in humans. Clin Biochem 2013;46:300-3.

15. Son JW, Kim S. Dipeptidyl peptidase 4 inhibitors and the risk of cardiovascular disease in patients with type 2 diabetes: a tale of three studies. Diabetes Metab J 2015;39:373-83.

16. Misra A, Garg A, Abate N, et al. Relationship of anterior and posterior subcutaneous abdominal fat to insulin sensitivity in nondiabetic men. Obes Res 1997:5:93-9.

17. Marinou K, Hodson L, Vasan SK, et al. Structural and functional properties of deep abdominal subcutaneous adipose tissue explain its association with insulin resistance and cardiovascular risk in men. Diabetes Care 2014;37:821-9.

18. Anand SS, Tarnopolsky MA, Rashid S, et al. Adipocyte hypertrophy, fatty liver and metabolic risk factors in South Asians: the molecula study of health and risk in ethnic groups (mol-SHARE). PLoS One 2011:6:e22112.

19. World Medical Association. World medical association declaration of Helsinki: ethical principles for medical research involving human subjects. JAMA 2013;310:2191-4.

20. Dudeja V, Misra A, Pandey RM, et al. BMI does not accurately predict overweight in Asian Indians in northern India. Br J Nutr 2001;86:105-12.
21. Goda K, Sasaki E, Nagata K, et al. Pancreatic volume in type 1 and type 2 diabetes mellitus. Acta Diabetol 2001;38:145-9.

22. Tanaka S, Kanazawa I, Notsu M, et al. Visceral fat obesity increases serum DPP-4 levels in men with type 2 diabetes mellitus. Diabetes Res Clin Pract 2016;116:1-6.

23. Chandalia M, Lin P, Seenivasan T, et al. Insulin resistance and body fat distribution in South Asian men compared to Caucasian men. PLoS One 2007;2:e812.

24. Abate N, Garg A, Peshock RM, et al. Relationships of generalized and regional adiposity to insulin sensitivity in men. $J$ Clin Invest 1995;96:88-98.

25. Balaban $\mathrm{YH}$, Korkusuz P, Simsek H, et al. Dipeptidyl peptidase IV (DDP IV) in NASH patients. Ann Hepatol 2007;6:242-50.

26. Miyazaki M, Kato M, Tanaka K, et al. Increased hepatic expression of dipeptidyl peptidase-4 in non-alcoholic fatty liver disease and its association with insulin resistance and glucose metabolism. Mol Med Rep 2012;5:729-33.

27. Petersen KF, Dufour S, Feng J, et al. Increased prevalence of insulin resistance and nonalcoholic fatty liver disease in Asian-Indian men. Proc Natl Acad Sci U S A 2006;103:18273-7.

28. Lee SA, Kim YR, Yang EJ, et al. CD26/DPP4 levels in peripheral blood and T Cells in patients with Type 2 diabetes mellitus. The Journal of Clinical Endocrinology \& Metabolism 2013:98:2553-61.

29. Lenhard JM, Croom DK, Minnick DT. Reduced serum dipeptidyl peptidase-IV after metformin and pioglitazone treatments. Biochem Biophys Res Commun 2004;324:92-7.

30. Green BD, Irwin N, Duffy NA, et al. Inhibition of dipeptidyl peptidase-IV activity by metformin enhances the antidiabetic effects of glucagon-like peptide-1. Eur J Pharmacol 2006;547:192-9.

31. Mannucci E, Pala L, Ciani S, et al. Hyperglycaemia increases dipeptidyl peptidase IV activity in diabetes mellitus. Diabetologia 2005;48:1168-72.

32. Pala L, Mannucci E, Pezzatini A, et al. Dipeptidyl peptidase-IV expression and activity in human glomerular endothelial cells. Biochem Biophys Res Commun 2003;310:28-31.

33. Wu L, Gong Q, Na R, et al. Dipeptidyl peptidase 4 concentration influenced by serum insulin levels rather than arterial stiffness index in type 2 diabetics. Int J Clin Exp Med 2015;8:6236-41.

34. Firneisz G, Varga T, Lengyel G, et al. Serum dipeptidyl peptidase-4 activity in insulin resistant patients with non-alcoholic fatty liver disease: a novel liver disease biomarker. PLoS One 2010;5:e12226.

35. Zhong J, Rao X, Deiuliis J, et al. A potential role for dendritic cell/macrophage-expressing DPP4 in obesity-induced visceral inflammation. Diabetes 2013;62:149-57.

36. Aso Y, Terasawa T, Kato K, et al. The serum level of soluble CD26/ dipeptidyl peptidase 4 increases in response to acute hyperglycemia after an oral glucose load in healthy subjects: association with high-molecular weight adiponectin and hepatic enzymes. Trans/ Res 2013;162:309-16.

37. Chandalia M, Cabo-Chan AV, Devaraj S, et al. Elevated plasma highsensitivity C-reactive protein concentrations in Asian Indians living in the United States. J Clin Endocrinol Metab 2003;88:3773-6.

38. Shrivastava U, Misra A, Mohan V, et al. Obesity, diabetes and cardiovascular diseases in India: public health challenges. Curr Diabetes Rev 2017;13:65-80.

39. Gupta R, Misra A. Epidemiology of microvascular complications of diabetes in South Asians and comparison with other ethnicities. $J$ Diabetes 2016;8:470-82. 